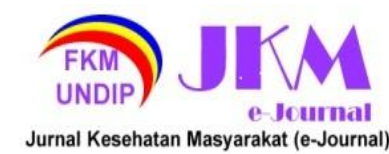

JURNAL KESEHATAN MASYARAKAT (e-Journal)

Volume 9, Nomor 5, September 2021

ISSN: 2715-5617 / e-ISSN: 2356-3346

http://ejournal3.undip.ac.id/index.php/jkm

\title{
ANALISIS IMPLEMENTASI PROGRAM ASI EKSKLUSIF DI PUSKESMAS SERING KECAMATAN MEDAN TEMBUNG
}

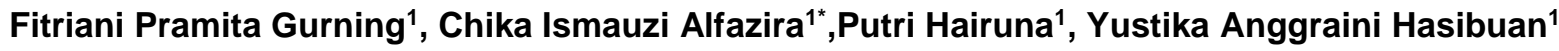 \\ ${ }^{1}$ Fakultas Ilmu Kesehatan Masyarakat Universitas Islam Negeri Sumatera Utara \\ *Corresponding Author: chikaismauzialfazira@gmail.com
}

\begin{abstract}
Exclusive breastfeeding is the best type of initial food for babies and up to 2 months of age. The low coverage of exclusive breastfeeding in the working area of the health center, often in Medan Tembung sub-district, is around 67 babies (35\%) who are given exclusive breastfeeding out of 191 babies, influenced by lack of participation from the mother pregnant and breastfeeding mothers to the exclusive breastfeeding program at puskesmas frequently. Therefore, the implementation of the exclusive breastfeeding program has become weak. The aim of this study was to determine the implementation of the exclusive breastfeeding program which included goals and objectives, the communication process (socialization), resources and characteristics of the program implementing agency. This method of research is effective. The research informants were 1 head of the puskesmas, 2 people in charge of the exclusive breastfeeding program, and 3 midwives for health workers. Data collection was through in-depth interviews with key informants and informants on triangulation and observations. The results showed that the implementation of exclusive breastfeeding programs in puskesmas is generally less successful. The program was implemented mentoring during push-ups and testing in the posyandu project. Communication in the program does not achieve the goals and objectives. The implementation of an exclusive breastfeeding program can be effectively implemented by increasing the social activities associated with the program according to the plan and by providing a support program for the program.
\end{abstract}

Keywords: Implementation, Program, Exclusive Breastfeeding

\section{PENDAHULUAN}

Pemberian ASI Eksklusif oleh Organisasi Kesehatan Dunia memberikan ASI saja tanpa makanan atau minuman bayi lainnya sejak lahir sampai berumur 6 bulan, tidak termasuk obatobatan dan vitamin. Ini tidak berarti bahwa pemberian ASI akan dihentikan setelah pemberian ASI khusus, tetapi akan diberikan kepada bayi hingga usia dua tahun. Organisasi Kesehatan Dunia (WHO) telah mensurvei lebih dari 3.000 peneliti dan telah menunjukan bahwa enam bulan menyusui adalah waktu yang paling optimal untuk pemberian ASI eksklusif. ${ }^{1}$ Menurut United Nations Internasional Children's Emergancy Fund (UNICEF), rata-rata pemberian ASI secara keseluruhan adalah sebesar $38 \%{ }^{2}{ }^{2}$

Sesuai peraturan pemerintah nomor 33 tahun 2012 adalah ASI yang diberikan kepada bayi sejak dilahirkan selama enam bulan, tanpa menambahkan atau mengganti dengan makanan dan minuman lain (tidak termasuk obat, vitamin, dan mineral.

Salah satu tujuan program SDG's (Sustainable Development Goals) adalah untuk mengakhiri semua bentuk malnutrisi dalam rencana strategi (renstra) meningkatkan presentase bayi kurang dari 6 bulan yang mendapatkan ASI Eksklusif dari $42 \%$ menjadi 50\% pada tahun 2019 nanti.

Berdasarkan Profil Kesehatan Indonesia tahun 2019, angka cakupan nasional bayi yang mendapat ASI Eksklusif tahun 2019 yaitu sebesar $67,74 \%$. Angka tersebut melebihi $50 \%$ target strategi tahun 2019. Prevalensi pemberian ASI di Provinsi Sumatera Utara pada tahun 2019 sebesar $50.35 \% .^{3}$

Dari hasil penelitian yang dilakukan, diperoleh data dari puskesmas sering tahun 2021 hanya 67 bayi (35\%) yang diberi ASI eksklusif dari 191 jumlah bayi. Sementara target nasional cakupan Asi eksklusif di tahun 2019 sebesar $50 \%$. Cakupan yang rendah ini dikarenakan tujuan dan sasaran program masih terbatas pada ibu hamil dan ibu menyusui, namun keberhasilan program tersebut dikarenakan banyaknya keluarga dan sumber daya manusia yang terlibat dalam program tersebut. Masih ada kegagalan berpartisipasi dalam program pemberian ASI Eksklusif.

\section{METODE PENELITIAN}

Desain penelitian ini adalah penelitian deskriptif dengan menggunakan pendekatan kualitatif. Pendekatan kualitatif adalah suatu metode penelitian yang dilakukan dengan tujuan 


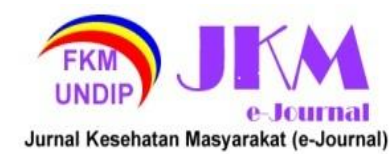

utama untuk membuat gambaran deskriptif tentang keadaan secara obyektif. Informan dalam penelitian ini terdiri dari 3 orang yaitu informan 1 kepala puskesmas, informan 2 penanggung jawab program Asi Ekslusif, dan informan 3 bidan tenaga kesehatan. Pengumpulan data dilakukan melalui wawancara mendalam dengan instrument penelitian adalah pedoman wawancara, alat tulis, dan alat perekam.

\section{HASIL DAN PEMBAHASAN Pelaksana Program}

Pemberian ASI secara eksklusif meningkatkan perlindungan yang maksimal terhadap malnutrisi, penyakit, kematian serta berkontribusi pada perkembangan anak. ${ }^{3}$ Studi menunjukkan bahwa riwayat menyusui terkait erat dengan perkembangan bayi. Anak-anak yang tidak mendapatkan ASI eksklusif lebih berisiko menderita stunting dibandingkan dengan anak yang diberikan ASI eksklusif. Hal tersebut menyebabkan kerugian dan dampak pembangunan karena kebutuhan gizinya tidak terpenuhi. ${ }^{4}$

Berdasarkan hasil dari wawancara, Komponen proses yang terdiri dari upaya yang telah dilakukan petugas untuk promosi program ASI eksklusif. Hambatan petugas dan kebutuhan petugas promosi program ASI eksklusif adalah bahwa upaya yang dilakukan petugas dalam promosi ASI eksklusif selama ini adalah penyuluhan, penyuluhan yang dilakukan hanya menganjurkan pada masyarakat. Hambatan petugas dalam promosi masih kurang kerjasama antara lintas program dan lintas sektor dan juga sasaran dari ASI ekslusif itu sendiri. Perlunya pejabat senior dalam program ASI Eksklusif adalah menambahkan media modern sebagai alat bantu, dengan bantuan seluruh stakeholder.

Pelaksanaan program pemberian AS Eksklusif di Puskesmas Sering belum optimal karena belum tepat pada sasaran dan tujuan yang ingin di capai. Karena tujuan penelitian hanya diberikan kepada orang tua yang sudah sampai di posyandu maka tujuan pencapaian target program tidak sejalan dengan kebijakan yang di tetapkan oleh Puskesmas yaitu sebesar $40 \%$ padahal SOP sudah tersedia di Puskesmas.

Keberhasilan dalam praktik pemberian ASI perlu ditinjau dari banyak perspektif. Sikap dan kemauan ibu untuk menyusui merupakan aset penting untuk keberhasilan menyusui. Selain itu, dukungan keluarga dan peran petugas kesehatan merupakan beberapa dari keberhasilan pemberian ASI.

\section{Proses Komunikasi (sosialisasi)}

Strategi komunikasi merupakan paduan dari perencanaan komunikasi (communication planning) dan manajemen (management communication) untuk mencapai suatu tujuan yang dapat diprediksi. Komunikasi merupakan cara atau langkah-langkah yang diambil untuk keberhasilan proses penyampaian pesan oleh seseorang kepada orang lain untuk memberitahu atau mengubah sikap, pendapat dan perilaku, baik secara langsung secara lisan maupun tidak langsung melalui media. ${ }^{5}$

Dalam bahwa dalam rangka menyusun strategi komunikasi diperlukan suatu pemikiran dengan memperhitungkan faktor-faktor pendukung dan faktor-faktor penghambat. Komponen-komponen berikut ini harus lebih diperhatikan dalam menentukan suatu strategi komunikasi, yakni: 6

a. Mengenali sasaran komunikasi atau komunikannya, yakni terhadap dua faktor dalam diri komunikan yaitu faktor frame of reference, dan faktor situasi dan kondisi

b. Pemilihan media komunikasi yang sesuai. Ada dua saluran/media komunikasi yakni melalui face to face atau tatap muka dan melalui media massa.

c. Pengkajian tujuan pesan komunikasi. Hal ini menentukan teknik komunikasi yang harus diambil, apakah informative, persuasuif, atu instruktif.

d. Peranan komunikastor dalam komunikasi, meliputi faktor daya tarik sumber (source attractiveness), dan faktor kredibilitas sumber. Kredibilitas oleh hafied cangara diartikan sebagai seperangkat persepsi tentang kelebihan-kelebihan yang dimiliki sumber sehingga diikuti atau diterima oleh khalayak atau penerima. ${ }^{7}$

Proses Komunikasi (sosialisasi) tentang program pemberian Asi Eksklusif di Puskesmas Sering jarang dilaksanakan dikarenakan kurangnya bentuk partisipasi dari ibu yang menyusui.Dan bentuk sosialisasi atau penyuluhan hanya dilakukan dengan ceramah biasa dan tidak ada menggunakan media apapun dalam penyampaian informasi. Pentingnya ASI Eksklusif dapat disampaikan melalui penyuluhan di masyarakat melalui kegiatan di posyandu setiap bulan, selain itu dengan konseling atau penyuluhan individu pada saat pasien atau sasaran sedang memeriksakan kehamilannya ke tempat pelayanan kesehatan terdekat. Kesadaran masyarakat masih kurang, sehingga sosialisasi yang dilakukan tidak berarti dan masyarakat tidak peduli akan pentingnya ASI Eksklusif. 


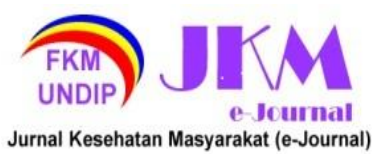

Berdasarkan hasil pengamatan peneliti, upaya yang dilakukan oleh petugas promosi pengelola program ASI eksklusif adalah penyuluhan kepada ibu-ibu hamil atau ibu yang mempunyai balita dan konseling pada saat ada kegiatan posyandu, tapi tidak fokus penyampian ASI saja.

\section{Sumber Daya}

Sumber daya dalam pelaksanaan program pemberian ASI Eksklusif di Puskesmas Sering masih kurang baik dari sisi tenaga, dana, maupun sarana prasarana. Sarana prasarana untuk menunjang program pemberian ASI Eksklusif di Puskesmas Sering tidak tersedia serta ruang pojok Laktasi belum ada.

Menurut UU No 36 Tahun 2014, tenaga kesehatan adalah setiap orang yang mengabadikan diri dalam bidang kesehatan dan mereka memiliki pengetahuan dan keterampilan melalui pendidikan dibidang kesehatan untuk jenis tertentu memerlukan kewenangan untuk melakukan pelayanan kesehatan. PERMENKES RI Nomor 15 Tahun 2013 (pasal 1 ayat 3), ruangan ini dilengkapi dengan prasarana untuk menyusui bayi , memerah ASI, menyimpan ASI perah, dan konseling menyusui disebut dengan fasilitas khusus menyusui dan atau memerah ASI yang dikenal sebagai ruang laktasi. ${ }^{1}$

Studi oleh Taveras, dkk tahun 2011 mengatakan bahwa tenaga kesehatan akan memberikan dampak yang signifikan terhadap praktik pemberian ASI pada bayi secara eksklusif, karena mereka diyakini memiliki pemahaman yang lebih baik tentang nutrisi sehat untuk tumbuh kembangnya. ${ }^{8}$ Diharapkan melalui program peningkatan ASI, manfaay ASI dapat dirasakan oleh masyarakat luas. Tidak ada dana khusus untuk menggalakkan program ASI Eksklusif, namun terkait dengan proyek lain beberapa di antaranya didanai oleh dana BOK (Bantuan Operasional Kesehatan) serta sarana untuk promosi program ASI eksklusif masih terbatas seperti alat peraga masih kurang dan juga perlu adanya media untuk penayangan slide dan video.

Menurut survei yang dilakukan oleh Murtiyarini dkk, pada tahun 2014 menyatakan bahwa dukungan dana, sarana dan prasarana yang memadai akan sangat membantu dalam efektifitas pengoperasian program. Salah satu komponen utama yang membentuk tim kerja yang efektif adalah mendukung sumber daya yang tepat, termasuk penyediaan peralatan yang sesuai. Dengan dukungan sumber daya tersebut, diharapkan pemberian ASI sendiri fapat dilakukan. $^{9}$
Berdasarkan hasil pengamatan, ditemukan bahwa selama kegiatan posyandu petugas yang turun kelapangan sangat kurang dan minimnya media / fasilitas untuk mempromosikan ASI. Hasil dari wawancara yang di dapatkan, Komponen proses yang terdiri dari upaya yang telah dilakukan petugas untuk promosi program ASI eksklusif, Hambatan petugas dan kebutuhan petugas promosi program ASI eksklusif adalah bahwa upaya yang dilakukan petugas dalam promosi ASI eksklusif selama ini adalah penyuluhan, penyuluhan yang dilakukan hanya menganjurkan pada masyarakat.

\section{Watak dan Sikap}

Kualitas dan karakteristik penampil seperti komitmen, kejujuran, dan sifat demokrasi. Jika tindakannya kebih baik, maka dia dapat melakukan kebijakan seperti yang diinginkan oleh pembuat kebijakan. Petugas pelaksana kebijakan sangat mendukung dengan adanya kebijakan ASI Eksklusif, karena ASI memiliki peran penting dan banyak manfaat yang terkandung didalamnya.

Pemahaman yang baik dari implementor dalam implementasi kebijakan ASI Eksklusif akan mempengaruhi keberhasilan dari adanya kebijakan tersebut. Menurut Laurence Green bahwa salah satu faktor karakteristik kepribadian paling berpengaruh dari perilaku manusia adalah faktor-faktor predisposisi (predispotition factor) yang terwujud terhadapan pendidikan, sikap, kepercayaan, kepercayaan diri, dan sebagainya. Watak dan sikap petugas yakni respon, komitmen dan pemahaman petugas dalam menjalankan program pemberian Asi Eksklusif di wilayah Puskesmas Sering sudah baik dimana terlihat responsif dengan melayani ibu menyusui saat kegiatan dilakukan dan memberikan tanggapan terhadap keadaan bayi yang terlihat pada saat berkunjung ke posyandu.

\section{KESIMPULAN}

Pelaksanaan program pemberian ASI Eksklusif di Puskesmas Sering belum optimal karena belum tepat pada sasaran dan tujuan yang ingin di capai. Sasaran dalam penelitian hanya diberikan kepada lbu yang yang datang ke posyandu saja sehingga dalam pencapaian target program belum sesuai dengan tujuan yang di tetapkan oleh Puskesmas. Sumber daya dalam pelaksanaan program pemberian ASI Eksklusif di Puskesmas Sering masih kurang baik dari sisi tenaga, dana, maupun sarana prasarana. Proses komunikasi (sosialisasi) jarang dilaksanakan, sosialisasi penyuluhan tidak menggunakan media apapun hanya seperti ceramah biasa. 


\section{SARAN}

Diharapkan adanya bentuk evaluasi secara berkesinambungan dan pembinaan terhadap petugas promosi kesehatan dan juga kaderkader di lapangan mengenai pemberian ASI eksklusif serta meningkatkan upaya pemberdayaan kepada masyarakat bagi pemegang program-program terkait. Untuk petugas promosi pengelolaan program Asi Eksklusif diharapkan adanya kegiatan rutin dalam penyampain bentuk penyuluhan yang berkesinambungan kepada masyarakat tidak hanya kepada ibu hamil dan menyusui namun juga disampaikan kepada pihak yang terkait. Keterbatasan dana untuk promosi program ASI eksklusif. Pedistribusian dana belum terprogram dengan baik begitu juga sarana untuk promosi masih perlu penambahan media promosi.

\section{DAFTAR PUSTAKA}

1. Haryono \& Setianingsih. Manfaat ASI Eksklusif Untuk Buah Hati Anda. Yogyakarta: Gosyen Publishing; 2019.

2. United Nations International Children's Emergency Fund. 2015.

3. Kementerian Kesehatan RI. Profil Kesehatan Indonesia. 2019. Jakarta: Kemenkes RI. 2019

4. Darmawan, D., \& Abadi, T. W. Strategi Komunikasi Bidan untuk Meningkatkan Partisipasi Ibu-ibu Menyusui dalam Program ASI Eksklusif di Jabon Sidoarjo. Jurnal IImu Komunikasi. 2019; 1(1), 39-52.

5. Fahmi, I., \& Siregar, Y. F. Analisis Implementasi Program Asi Ekslusif Di Dinas Kesehatan Kabupaten Tapanuli Selatan. Jurnal Kesehatan IImiah Indonesia (Indonesian Health Scientific Journal). 2018; 3(2), 159-164.

6. Octavia, A. D., \& Mardiana, M. Analisis Implementasi Kebijakan Asi Eksklusif. HIGEIA (Journal of Public Health Research and Development). 2020; 4(4).

7. Sari, Y. S. Analisis implementasi program pemberian asi eksklusif di puskesmas brangsong 02 kabupaten kendal. Jurnal Kesehatan Masyarakat Universitas Diponegoro. 2013; 2(1), 18750.

8. Prastia, T. N., azhar, e. H., \& isnani, s. A. Studi kualitatif praktik pemberian asi pada bayi usia 0-4 bulan di wilayah kerja puskesmas abadijaya kota depok. Jurnal Kesehatan Masyarakat. 2019; 7(1).

9. Murtiyarini. Evaluasi Pelaksanaan Konseling Menyusui. Jurnal Kesehatan Masyarakat Nasional. 2014; 9(1). 